\title{
KETERANGAN HAK WARIS YANG DIBUAT OLEH NOTARIS DALAM RANGKA UNIFIKASI HUKUM
}

\author{
Annis Setiawan \\ Magister Kenotariatan, Fakultas Hukum, Universitas Narotama Surabaya \\ Email: annissetiawan12@gmail.com
}

\begin{abstract}
ABSTRAK
Hukum waris yang berlaku di Indonesia hingga saat ini belum menuju pada unifikasi hukum yang seharusnya dapat menyelesaikan sengketa. Adanya ketentuan yang berbeda dalam pembuatan akta keterangan hak waris merupakan sumber permasalahan yang seringkali terjadi dalam pembagian waris. Kondisi tersebut menjadi alasan dibutuhkannya Notaris sebagai satu-satunya pejabat yang berwenang membuat akta keterangan waris. Penelitian ini menganalisis kewenangan Notaris dalam membuat Akta Keterangan Hak Waris dan kedudukan hukum keterangan hak waris selain yang dibuat oleh notaris. Metode penelitian yang digunakan adalah penelitian hukum normatif, yaitu penelitian hukum yang dilakukan dengan cara meneliti bahan pustaka atau bahan hukum sekunder sedangkan pendekatan masalah dilakukan dengan menggunakan pendekatan undang-undang dan pendekatan konseptual. Hasil penelitian ini mennunjukkan bahwa Notaris berwenang membuat Keterangan Hak Waris berdasarkan Undang-Undang Jabatan Notaris dan Keterangan Hak Waris yang dibuat oleh notaris merupakan akta otentik. Keberadaan Keterangan Hak Waris bagi penduduk Indonesia pribumi asli mempunyai kekuatan pembuktian di bawah tangan sedangkan keterangan hak waris yang dibuat oleh Balai Harta Peninggalan merupakan akta otentik.
\end{abstract}

Kata Kunci: Unifikasi hukum, Keterangan Hak Waris, Notaris

\begin{abstract}
The inheritance law in force in Indonesia until now has not yet led to a legal unification that should have been able to resolve disputes. The existence of different provisions in making inheritance rights certificates is a source of problems that often occur in the distribution of inheritance. This condition is the reason for the need for a Notary as the only official authorized to make a certificate of inheritance. This study analyzes the authority of the Notary in making the Deed of Inheritance Rights and the legal status of inheritance rights other than those made by the notary. The research method used is normative legal research, namely legal research conducted by examining library materials or secondary legal material while the problem approach is carried out using a legal approach and conceptual approach. The results of this study indicate that the Notary is authorized to make Information on Inheritance Rights based on the Act of Notary Position and the Description of Inheritance Rights made by a notary is an authentic deed. The existence of information on inheritance rights for indigenous indigenous Indonesians has the power of proof under the hands while the information on inheritance rights made by the Heritage Office is an authentic deed.
\end{abstract}

Key words: Legal Unification, Information on Inheritance Rights, Notary 


\section{PENDAHULUAN}

Hukum waris yang berlaku di Indonesia hingga saat ini belum menuju pada unifikasi hukum yang seharusnya dapat menyelesaikan sengketa, karena : adanya perkawinan campur, banyaknya penggolongan penduduk yang pemberlakuan hukum pada masing-masing golongan penduduk tersebut sejak zaman pemerintahan Hindia Belanda dan juga karena mayoritas penduduk di Indonesia bertahan pada adat-istiadat, tradisi, agama dan kepercayaan yang dapat bertentangan antara yang satu dengan yang lain.

Bukti nyata bahwa di Indonesia saat ini belum terbentuk unifikasi hukum yaitu berdasarkan pada ketentuan Pasal 111 ayat (4) Peraturan Kepala Badan Pertanahan Nasional Nomor 3 Tahun 1997 tentang Ketentuan Pelaksanaan Peraturan Pemerintah Nomor 24 Tahun 1997 tentang Pendaftaran Tanah (Perkaban No. 3 Th. 1997) yang menentukan bahwa :

1. Bagi warganegara Indonesia penduduk asli surat keterangan ahli waris yang dibuat oleh para ahli waris dengan disaksikan oleh 2 (dua) orang saksi dan dikuatkan oleh Kepala Desa/Kelurahan dan Camat tempat tinggal pewaris pada waktu meninggal dunia.

2. Bagi warganegara Indonesia keturunan Tionghoa akta keterangan hak mewaris dari Notaris, dan

3. Bagi warganegara Indonesia keturunan Timur Asing lainnya surat keterangan waris dari Balai Harta Peninggalan.

Dengan adanya penggolongan penduduk dan pembagian pembuatan keterangan hak waris di Indonesia sebagaimana telah diuraikan di atas sudah dapat dipastikan akan menimbulkan permasalahan hukum, terutama pelanggaran terhadap peraturan perundang-undangan yang berlaku di Indonesia, antara lain : Undang-undang Nomor 12 Tahun 2006 tentang Kewarganegaraan, Undang-undang Nomor 23 Tahun 2006 tentang Administrasi Kependudukan dan Undang-undang Nomor 40 Tahun 2008 Tentang Penghapusan Diskriminasi Ras dan Etnis.

\section{RUMUSAN MASALAH}

1) Apakah kewenangan Notaris dalam membuat Akta Keterangan Hak Waris? 
2) Apa kedudukan hukum keterangan hak waris selain yang dibuat oleh notaris?

\section{METODE PENELITIAN}

Penelitian ini menggunakan metode penelitian hukum normatif yang dilakukan untuk mencari pemecahan masalah atas permasalahan hukum yang ada. Pendekatan penelitian yang digunakan adalah pendekatan undang-undang (statute approach) dan pendekatan konseptual (conceptual approach).

\section{PEMBAHASAN}

\section{Kewenangan Notaris Membuat Keterangan Hak Waris}

Wet op het notarisambt yang mulai berlaku tanggal 3 April 1999, Pasal 1 huruf a disebutkan bahwa "Notaris : de ambtenaar", Notaris tidak lagi disebut sebagai Openbaar Ambtenaar sebagaimana tercantum dalam Pasal 1 Wet op het notarisambt yang lama (diundangkan tanggal Juli 1842, Stb. 20). Tidak dirumuskan lagi Notaris sebagai Openbaar Ambtenaar, sekarang ini tidak dipersoalkan apakah Notaris sebagai Pejabat Umum atau bukan, dan perlu diperhatikan bahwa istilah Openbaar Ambtenaar dalam konteks ini tidak bermakna umum, tetapi bermakna Publik. Amb pada dasarnya adalah Jabatan Publik. Dengan demikian Jabatan Notaris adalah Jabatan Publik tanpa perlu atribut Openbaar ${ }^{1}$.

Jika ketentuan dalam Wet op het notarisambt di atas dijadikan rujukan untuk memberikan pengertian yang sama terhadap ketentuan Pasal 1 angka 1 UUJN yang menyebutkan Notaris adalah Pejabat Umum yang berwenang membuat akta otentik dan kewenangan lainnya sebagaimana dimaksud dalam Pasal 15 ayat (2) dan (3) UUJN ${ }^{2}$, maka Notaris sebagai pejabat publik yang bermakna hukum bukan pejabat publik di bidang pemerintahan. Notaris sebagai pejabat publik yang menghasilkan suatu produk berupa akta otentik. Akta otentik tersebut dapat dijadikan sebagai bukti yang sempurna apabila terjadi sengketa di pengadilan.

Notaris berwenang memiliki kewenangan untuk membuat surat keterangan, salah satunya yaitu membuat surat keterangan waris atau keterangan hak waris,

${ }^{1}$ Habib Adjie, Sanksi Perdata dan Administratif Terhadap Notaris Sebagai Pejabat Publik, edisi kedua, Refika Aditama, Bandung, 2009, h. 30-31

${ }^{2}$ Ibid., hal. 31 
melakukan pengesahan tandatangan, memberikan pelayanan dan penyuluhan hukum serta sebagai penasehat hukum (legal advisor) bagi seluruh warganegara tanpa memandang, suku, ras dan agama. Fakta yang terjadi sampai dengan saat ini hukum waris yang berlaku di Indonesia belum menuju pada unifikasi hukum secara mutlak. Keberadaan keterangan hak waris selain yang dibuat oleh notaris di Indonesia, kewenangan lainnya juga diberikan kepada beberapa instansi pemerintahan.

Memang sejak pemerintahan Hindia Belanda tidak ada aturan pasti mengenai pembuatan Keterangan Hak Waris harus dibuat di notaris, namun pembuatan keterangan hak waris di Notaris tersebut merupakan suatu kebiasaan yang dilakukan bagi penduduk Tionghoa. Sejak diundangkannya UUJN, maka pembuatan keterangan hak waris oleh notaris memiliki kepastian hukum sebagaimana diatur dalam ketentuan Pasal 15 ayat (3) UUJN, sehingga bagi warganegara/penduduk Indonesia keturunan Tionghoa, keturunan Belanda/Eropa serta Timur Asing yaitu Jepang dan juga untuk pribumi yang menundukan diri secara diam-diam kepada Kitab Undang-undang Hukum Perdata akan membuat keterangan hak waris di Notaris. Penundukan diri artinya bahwa setiap orang mempunyai kebebasan menentukan hukum warisnya meskipun adanya penggolongan.

Notaris sebagai pejabat umum yang mempunyai kewenangan membuat keterangan hak waris berdasarkan Pasal 15 ayat (3) UUJN, dan keterangan hak waris yang dibuat oleh notaris merupakan akta otentik yang dapat dijadikan sebagai alat bukti yang sempurna apabila terjadi sengketa di pengadilan. ${ }^{3}$ Namun notaris tidak bertanggung jawab dan tidak dapat dituntut oleh para ahli waris perihal pembuatan keterangan hak waris sebagaimana peristiwa hukum tersebut di atas, sebab notaris dalam membuat keterangan hak waris telah didukung oleh data-data yang benar dan obyektif.

Berdasarkan hal-hal tersebut di atas, maka dapat diambil suatu kesimpulan:

1. Notaris sebagai satu-satunya pejabat umum yang layak mempunyai kewenangan untuk membuat keterangan hak waris sebagaimana diatur dalam ketentuan Pasal 15

${ }^{3}$ Hatta Isnaini Wahyu Utomo, "Pelaksanaan Tugas Jabatan Notaris : Bahan Diskusi Dalam Persiapan Menghadapi Ujian Kode Etik Notaris", disampaikan pada acara Belajar Bareng Alumni, Univeritas Narotama, 12 Februari 2017 
ayat (3) UUJN dan keterangan waris yang dibuat oleh notaris merupakan akta otentik

2. Notaris sebagai satu-satunya pejabat umum yang berwenang membuat akta otentik sebagaimana diatur dalam pasal 1 Peraturan Jabatan Notaris di Indonesia (PJN), pasal 1867 BW, pasal 1868 BW, HIR, R.Bg. dan UUJN tentang akta otentik yang dapat dijadikan bukti yang sempurna pada penyelesaian sengketa waris ;

3. Keterangan Hak Waris yang dibuat oleh notaris selaku pejabat ahli tentang waris KUHPerdata berdasarkan kewenangan yang dipercayakan kepada notaris dan didasarkan pada data-data/dokumen-dokumen pendukung terutama tentang subyek hukum waris ;

4. Notaris sebagai satu-satunya pejabat ahli yang dapat membuat Keterangan Hak Waris berdasarkan ketentuan dalam KUHPerdata yang menuliskan bagian-bagian bagi masing-masing ahli waris (legitieme portie) dan dilakukan penghitungan bilamana ada tuntutan dari salah satu atau lebih ahli warisnya;

5. Keterangan Hak Waris yang dibuat notaris bukanlah dasar pemikiran notaris, namun pembuatannya berdasarkan pada dokumen/dokumen atau data-data pendukung yang diperlihatkan kepada notaris. ${ }^{4}$

Dengan demikian berdasarkan uraian-uraian tersebut di atas, bahwa berdasarkan pada Pasal 15 ayat (3) UUJN mengenai kewenangan notaris untuk membuat Keterangan Hak Waris bagi golongan Tionghoa, keturunan Belanda/Eropa serta Timur Asing yaitu Jepang tetapi juga berlaku bagi golongan pribumi yang menundukan diri secara diam-diam kepada Kitab Undang-undang Hukum Perdata, maka berdasarkan pada Pasal 2 Undang-undang Nomor 12 Tahun 2006 tentang Kewarganegaraan Republik Indonesia yang menyatakan bahwa "Yang menjadi Warga Negara Indonesia adalah orang-orang bangsa Indonesia asli dan orang-orang bangsa lain yang disahkan dengan undang-undang sebagai warga Negara”, Undang-undang Nomor 23 Tahun 2006 Tentang Administrasi Kependudukan dan Undang-undang Nomor 40 Tahun 2008 Tentang Penghapusan Diskriminasi Ras dan Etnis yang tidak lagi membedakan penggolongan penduduk sehingga Keterangan Hak Waris yang dibuat

${ }^{4}$ Habib Adjie, Pembuktian Sebagai Ahli Waris Dengan Akta Notaris: Dalam Bentuk Akta Keterangan Ahli Waris, Mandar Maju, Bandung, 2008, h. 12 
oleh notaris memberikan kepastian hukum bagi ahli waris yang menerima harta warisan pewaris, selain itu bahwa keterangan hak waris yang dibuat oleh notaris merupakan akta otentik yang dapat dijadikan bukti yang sempurna apabila terjadi sengketa waris di pengadilan.

\section{Kedudukan Hukum Keterangan Hak Waris Selain Yang Dibuat Oleh Notaris}

Kemajemukan penduduk di Indonesia yang memiliki perbedaan suku, ras dan agama di setiap daerah tentunya memiliki aturan hukum yang berbeda dalam hal pewarisan. terutama dalam pembuatan keterangan hak waris. Keterangan hak waris yang belaku hingga saat ini belum menuju unifikasi hukum yang seharusnya dapat menyelesaikan sengketa, karena adanya perkawinan campur, perbedaan agama, perbedaan adat/budaya dan adanya penggolongan penduduk. ${ }^{5}$

Keberadaan keterangan hak waris selain yang dibuat oleh notaris di Indonesia, kewenangan lainnya juga diberikan kepada beberapa instansi pemerintahan yang didasarkan pada ketentuan surat Direktur Jenderal Agraria a.n. Menteri Dalam Negeri tertanggal 20 Desember 1969 No. Dpt/12/63/12/69 tentang surat keterangan warisan dan pembuktian kewarganegaraan juncto ketentuan pasal 42 ayat 1 PP No 24 Tahun 1997 tentang Pendaftaran Tanah juncto ketentuan pasal 111 ayat 1 huruf c Peraturan Menteri Negara Agraria/Kepala Badan Pertanahan Nasional No. 3 Tahun 1997 tentang Ketentuan Pelaksanaan Peraturan Pemerintah No. 24 Tahun 1997 Tentang Pendaftaran Tanah, yang menyatakan :

surat tanda bukti sebagai ahli waris yang dapat berupa :

1) wasiat dari pewaris, atau

2) putusan Pengadilan, atau

3) penetapan hakim/Ketua Pengadilan, atau

4) - bagi warganegara Indonesia penduduk asli: surat keterangan ahli waris yang dibuat oleh para ahli waris dengan disaksikan oleh 2 (dua) orang saksi dan dikuatkan oleh Kepala Desa/Kelurahan dan Camat tempat tinggal pewaris pada waktu meninggal dunia ;

- bagi warganegara Indonesia keturunan Tionghoa : akta keterangan hak mewaris dari Notaris ;

- bagi warganegara Indonesia keturunan Timur Asing lainnya: surat keterangan waris dari Balai Harta Peninggalan.

\footnotetext{
${ }^{5}$ Hajar M, Polemik Hukum Waris, Suska Press, Jakarta, 2014, hal. 41
} 
Bagi warganegara Indonesia penduduk asli surat keterangan ahli waris yang dibuat oleh para ahli waris dengan disaksikan oleh 2 (dua) orang saksi serta disaksikan dan dibenarkan oleh Kepala Desa/Kelurahan dan dikuatkan oleh Camat tempat tinggal pewaris pada waktu meninggal dunia. Dengan demikian, maka para ahli waris harus membuat Surat Pernyataan Ahli Waris sendiri dengan menerangkan mengenai pewaris, tempat tinggal terakhir pewaris, waktu meninggalnya pewaris, ada/tidaknya pasangan hidup pewaris, dan para ahli warisnya dan Surat Pernyataan Ahli Waris tersebut akan ditandatangani oleh para ahli waris dan saksi, selanjutnya disaksikan dan dibenarkan oleh Kepala Desa/Kelurahan dan dikuatkan oleh Camat tempat pewaris tinggal. ${ }^{6}$

Dalam praktek sehari-harinya Surat Pernyataan Waris yang dibuat oleh para ahli waris sendiri seringkali terjadi konflik interen (interest conflic) antara ahli waris, karena dalam pembuatan surat pernyataan ahli waris ada kemungkinan tidak mencantumkan seluruh ahli waris dalam surat pernyataan ahli waris tersebut sehingga terjadi sengketa warisan sampai di pengadilan.

Surat Pernyataan Ahli Waris yang dibuat para ahli warisnya sendiri memiliki banyak kelemahan, antara lain :

1. Adanya konflik interen (interest conflic) antara ahli waris yang akan mengakibatkan keretakan hubungan dalam keluarga ;

2. Surat Pernyataan Ahli Waris merupakan surat di bawah tangan;

3. Ahli waris tidak pernah mengetahui perihal ada/tidaknya surat wasiat yang dibuat oleh pewaris.

Keterangan Hak Waris yang dibuat oleh Kantor Balai Harta Peninggalan diperuntukkan bagi warganegara Indonesia keturunan Timur Asing lainnya termasuk keturunan Arab, India dan Pakistan. Pelaksanaannya didasarkan pada "Pasal 14 ayat (1) Instruksi voor de gouvernements staatsblad 1916 No. 517 jo. Peraturan Menteri Negara/Kepala BPN No. 3 Tahun 1997 tentang Ketentuan Pelaksanaan PP No. 24 Tahun 1997"7.

\footnotetext{
${ }^{6}$ Udin Narsudin, Keterangan Waris Keterangan Ahli Waris Dalam Pluralisme Sistem Hukum Waris Di Indonesia : Dalam Perspektif Kewenangan Notaris, Gaung Persada, Bandung, 2016, h. 34

7 Taufik H. Simatupang, Penguatan Kinerja Unit Balai Harta Peninggalan, Balitbangkumham Press, Jakarta, 2018, hal. 103
} 
Definisi Balai Harta Peninggalan (BHP) adalah lembaga yang mempunyai tugas mengawasi penyelesaian harta warisan yang ahli warisnya masih di bawah umur, baik pewaris maupun ahli waris, tunduk pada hukum perdata Barat. Bagi warganegara Arab, India dan Pakistan, apabila ingin membuat keterangan hak waris harus datang ke Kantor Balai Harta Peninggalan

Berdasarkan hal-hal tersebut di atas, maka Kantor Balai Harta Peninggalan akan membuat keterangan hak waris berdasarkan data-data/dokumen-dokumen pendukung. Keterangan Hak Waris yang dibuat oleh Kantor Balai Harta merupakan akta otentik yang dapat dijadikan sebagai bukti yang sempurna apabila terjadi sengketa waris di pengadilan. Kedudukan Balai Harta Peninggalan adalah suatu lembaga yang berwenang membuat keterangan hak waris bagi warganegara India, Arab dan Pakistan, berbeda dengan notaris yang merupakan pejabat yang berwenang membuat keterangan hak waris.

Dengan demikian, unifikasi hukum waris di Indonesia sangat penting karena untuk memperoleh jaminan kepastian hukum melalui penerapan hukum waris yang sama bagi seluruh warganegara/penduduk Republik Indonesia sesuai KUHPerdata yang berlaku saat ini, maka Pemerintah Republik Indonesia diharapkan segera mengeluarkan suatu peraturan/regulasi/Undang-undang tentang unifikasi yang mewajibkan seluruh warganegara/penduduk Indonesia untuk membuat keterangan hak waris pada pejabat yang berwenang yaitu notaris.

\section{PENUTUP}

\section{Kesimpulan}

Notaris merupakan satu-satunya pejabat ahli yang layak berwenang membuat keterangan hak waris yang merupakan akta otentik bagi seluruh penduduk/warganegara Indonesia tanpa membedakan etnis/suku, agama dan golongan serta dapat menyelesaikan permasalahan waris karena perkawinan campur sebagai dasar untuk terjadinya unifikasi hukum waris

Keberadaan Keterangan Hak Waris bagi penduduk Indonesia pribumi asli mempunyai kekuatan pembuktian di bawah tangan sedangkan keterangan hak waris yang dibuat oleh Balai Harta Peninggalan merupakan akta otentik. Keterangan Hak 
Waris yang dibuat oleh penduduk Indonesia pribumi asli berupa surat pernyataan ahli waris yang mempunyai kekuatan pembuktian sebagai akta di bawah tangan yang rawan konflik, karena adanya konflik interen ( interest conflic) antara ahli waris

\section{Saran}

Perlu segera diatur dalam Peraturan Perundang-Undangan mengenai unifikasi dalam pembuatan keterangan waris untuk segala golongan penduduk yang kewenangan pembuatannya hanya diserahkan kepada Notaris saja. Hal ini untuk memberikan kepastian hukum dan perlindungan hukum bagi masyarakat yang membutuhkan surat keterangan waris dan menghapus terjadinya diskriminasi yang terjadi akibat ketentuan yang berbeda mengenai pembuatan keterangan waris.

\section{DAFTAR PUSTAKA}

Habib Adjie, Sanksi Perdata dan Administratif Terhadap Notaris Sebagai Pejabat Publik, edisi kedua, Refika Aditama, Bandung, 2009

Hatta Isnaini Wahyu Utomo, "Pelaksanaan Tugas Jabatan Notaris : Bahan Diskusi Dalam Persiapan Menghadapi Ujian Kode Etik Notaris”, disampaikan pada acara Belajar Bareng Alumni, Univeritas Narotama, 12 Februari 2017

Habib Adjie, Pembuktian Sebagai Ahli Waris Dengan Akta Notaris: Dalam Bentuk Akta Keterangan Ahli Waris, Mandar Maju, Bandung, 2008

Hajar M, Polemik Hukum Waris, Suska Press, Jakarta, 2014

Udin Narsudin, Keterangan Waris Keterangan Ahli Waris Dalam Pluralisme Sistem Hukum Waris Di Indonesia : Dalam Perspektif Kewenangan Notaris, Gaung Persada, Bandung, 2016

Taufik H. Simatupang, Penguatan Kinerja Unit Balai Harta Peninggalan, Balitbangkumham Press, Jakarta, 2018 